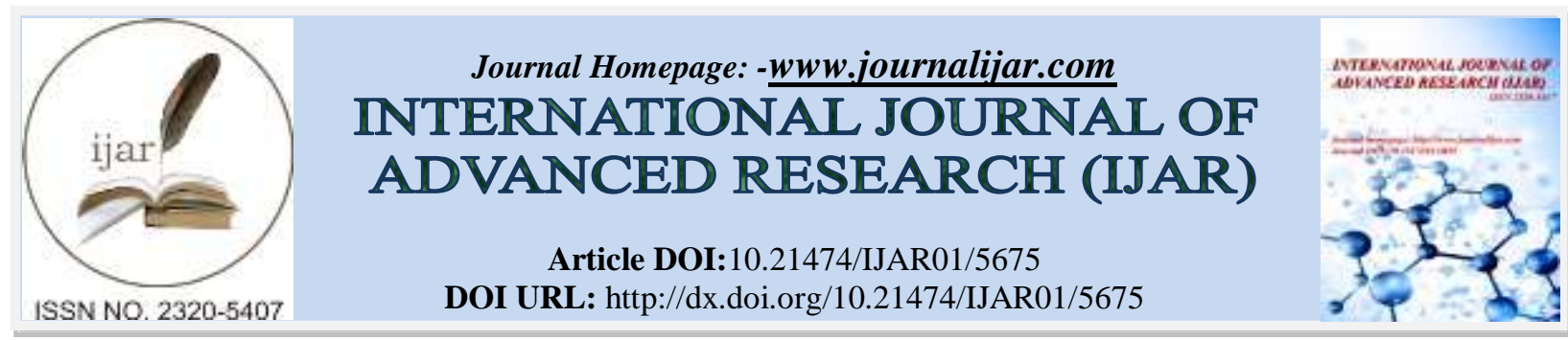

RESEARCH ARTICLE

\title{
FACTORS THAT AFFECT COMMUNITY PARTICIPATION IN THE IMPLEMENTATION OF SCHOOL IMPROVEMENT PROGRAM IN PRIMARY SCHOOLS OF DAMOT WOIDE DISTRICT, WOLAITA ZONE.
}

\author{
Dimo Didana Dinie(MA). \\ Lecturer ,Institute of Education and Professional Development Studies, Department of Educational Leadership and \\ Management. Mettu University, Mettu Ethiopia.
}

\section{Manuscript Info}

Manuscript History

Received: 20 August 2017

Final Accepted: 22 September 2017

Published: October 2017

Keywords:-

Community

Implementation, School program.

\section{Abstract}

The purpose of this study was to assess the factors that affect community participation in the implementation of School improvement program in primary schools of Damot Woide District /Woreda, Wolaita Zone. Descriptive survey design was employed to carry out this study. The survey sample consisted of 8 primary schools, 16 school principals , 129 teachers, 1 woreda education office expert and 1 educational office head, 24 PTA, 40 SIC, 8 KETB and 2 supervisors. These groups of samples were selected using purposive sampling and simple random sampling techniques. Data collecting instruments like questionnaire, semi-structured interview, document analysis and FGD were used to collect data.. To analyze the data collected through questionnaire, mean, standard deviation and weighted mean were employed. The major findings of the study were: The sample school had lack of community participation in decision making process of the school management and lack of good governance and leadership skills of the principal; lack of well-developed school policies, rules, regulation, norms and no appropriate strategy for the school to encourage and provide community services, information about school improvement program; poor follow up of the community to their children in close relation to the school and lack of Participation of community in different school meetings to discuss effectiveness and efficiency of the school. The major conclusion of the study were the schools lack welldeveloped school polices rules, regulation and norms to participate the community as a member of the school. In most cases, the reluctance of the community to participate actively in School Improvement Program due to lack of good governance and poor quality of principal in leadership skill, poor commitment of the school community (teachers, PTA, KETB and SIC) to involve the community in School Improvement Program and weak strategy for the school to provide community services and recent information about School Improvement Program are among the factors that contribute to the low level of community participation in School Improvement Program. On the basis of these major findings and conclusion, it is recommended that the school principals and teachers should have the responsibilities to furnish parent community and the whole community with clear and 
accurate information regarding the objective of education, school goals and program, prepare training programs for parents to work together with the school.

Copy Right, IJAR, 2017,. All rights reserved.

\section{Introduction:-}

\section{Background of the Study:-}

Education is a major foundation of societal progress. It is the basic and effective instrument by which human beings adopts nature according to their needs. The World Bank (1988) asserts that without education, development will not occur. Only educated people can command the skills necessary for sustainable economic growth and for a better quality of life. Anderson (1992) says "a child who has gained quality education will have a better chance of leading a healthy and secured life. It is not only the child who benefits from being Educated but also the Nation, because Education and Economic performance go together. Improvements in education increase national economic growth and bring broad social benefits."

The participation rate of primary school is growing from time to time, but the provision of quality of education is the problem of the country. Of course, nowadays providing quality education is the main problem of our country. It is also concern of nations in the world as a whole. It is for this reason that many countries of the world are undertaking different initiatives to produce quality education to their students. Ethiopia is included in the project (report of SIP meeting, 2003). Thus, in addition to expanding access to education, the question of quality is becoming the burning issue of the time. It was a response of this issue that, Ethiopia has at present, stated the school improvement programs (SIP) to provide quality education.

The Transitional Government of Ethiopia (TGE, 2004) issued a New Education and Training Policy to respond to the successively accumulated deep rooted problems related to primary, secondary and higher educational relevance. Quality has especially been found in a very worrying condition. The General Quality Assurance Package Manual, (MOE,2007) has also suggested that putting in to practice to design a General Educational Quality Improving package (GEQIP) that contains six main programs such as; Teachers Development Program (TDP), School Improvement Program (SIP), Information Communication Technology Program (ICT), Education Leadership and Management Improvement Program, Civic and Ethical Education Program and Curriculum Improvement Program began from the second half of 2006 all over the country. In line with this, in Ethiopia as indicated in MOE (2007) document of SIP, the MOE address four major domains to improve schools. The domains are: Teaching and learning, learning environment, community participation and leadership and management. Current Practice of Community Participation in School Improvement Program is the centre of the interest of my study.

Beginning from 1999/2000 E.C, MOE and Regional Educational Bureaus have given schools written materials like blue print, framework, handbooks and other guidelines and checklist through Woreda/ District education office start to implement school improvement Program effectively. Thus, the research might help to assess current practice of community participation in SIP and factors that hindering community participation of Primary schools of Damot Woide District/Woreda, Wolaita Zone. This indicates that the people of poor countries like Ethiopia need to organize and mobilize resources and complement the efforts of their governments in their respective countries in order to achieve a better life. In connection to this, there seems to exist an active local community participation in the promotion of educational facilities and services in some of the regional states of Ethiopia, particularly in Primary schools of Damot Woide District/Woreda, Wolaita Zone surrounding community has active Community participation has a great role in the implementation of school improvement program.

Schools exist within the context of parents, community, school districts, other educational organization and institutions and levels of government. Each of them has an impact on school and through school on pupils. Schools are somewhat like spiders" web. As the aim of spiders" "web" is to catch unwary insects so are schools to the learning of pupils. Schools Secrete partnership "web" with all individuals, groups, organizations and institutions which have responsibility for the growth and development of pupil. Therefore, to improve the quality of education and student's achievement, community participation is a vital component(Stoll, and Dean filch 1996).

The parents that contribute for the school improvement described by strong senses of partnership and they contribute a lot to pupils' success. They support schools by providing their knowledge, skill and resources. The school 
surrounding community should support schools in various aspects. The community has to participate in school development programs and has to make financial and material support. Pupils have to be involved in decision making in school development programs and they have to be encouraged to take responsibility in day to day routine work at classroom level. School districts support school in providing equitable and purposeful distribution of resources, not only monetary but also human, material and psychological support. There are other partners such as non-government organization (NGOs), charitable organizations, teachers unions, Universities etc. that could support schools in their improvement efforts. Thus, this research study was intended to assess current factors affecting community participation in the implementation of School Improvement in Damot Woide District primary schools.

\section{Statement of the Problem:-}

The achievement of high quality education, the capacity of schools has to be developed. The quality of education is composed of three interrelated dimensions, the quality of human and material resources available for teaching (inputs), the quality of teaching practices (process) and the quality of the results (out puts and out comes). By strengthening the internal conditions of the schools, what Ethiopia so far has undertaken to provide quality education is promising. Based on the Education and Training Policy Promulgated in 1994, the education management system is decentralized to the grass root level. The guideline prepared by Ministry of Education in 1994 E.C indicates, the duties and responsibilities of KETB, PTA and SIC to help them actively participate in school activities and facilitate school community relationship(MOE: the SIP guideline Amharic version 2007).

Even though, the activities undertaken to improve the quality of education in the country are promising, they are not in a position to enable students to achieve high learning out come with its dimensions. The outcome dimensions are academic, social, emotional, cultural, and environmental. Thus, taking the experiences of the schools that have good performance in the country and the experiences of other countries, Ethiopia has started a school improvement program (SIP) that is aimed at improving the learning outcome of students. The school improvement framework and other guidelines are prepared with focus on the four main domains which are learning and teaching, school environment, leadership and management and community involvement (MOE, the SIP/ school improvement program/guideline, Amharic version 2007). This is a new initiative that schools are to implement. While current community participation is very important to implementing School Improvement Program in the primary and general secondary school, there are factors hindering the parent participation and resistances that hinder its realization in active community participation. As Ayalew (1991) stated, people working in an organization established social relationship and when a change disrupts their relationship, they resist either overtly or covertly to maintain the existing situation.

According to the Federal Ministry of Education (MOE) improving school and students success is not achievable unless government efforts are supported by community participation. The MOE, in its five year plan (ESDP IV) specified that community would contribute money, labor and local materials and through its representatives. The PTA and KTEB get involved in the day to day management of school. Furthermore, the ministry of education (2005) notes that although community participation in the contribution of finance and educational materials is increasing from time to time, further effort are needed to improve school community relationship. The main objective of school improvement program in community participation is to enhance students' achievement. In 2016 the mean achievement scores in the overall tested was found low and about 769/45\%/of students in grade 8 were unable to score at least pass mark. Finally, to improve these results needs active current community participation.

Thus, while the study, mentioned above considered the case in view of their respective area, and the Ministry of Education put the problems at a general level. The existence and cause of the problem of community participation has largely remained an unstudied area when it comes to primary school of Wolaita zone. The researcher made preliminary investigation based on Woreda/District Education office report on the situation identified researchable problem of low level of community participation of Primary schools in the Zone.

In line with this, the study was attempted and answered the following basic research questions.

1. What are the School-community related factors/challenges that affect the community participation in the implementation of School Improvement Program in Primary schools of Damot Woide District/Woreda, Wolaita Zone?

2. What measure should be taken for the factors/challenges that are hindering community participation in the implementation of School Improvement Program in Primary schools in the study areas? 


\section{Objectives of the study:- General objective:-}

The main objective of this study was to assess the factors that affect community participation in the implementation of School improvement program in primary schools of Damot Woide District/Woreda, Wolaita Zone.

\section{Specific objectives:-}

The specific objectives of this study were:

1. To identify factor that affect current community participation in the implementation of school improvement program in primary schools of Damot Woide District /Woreda, Wolaita Zone?

2. To determine factors related to school community that affecting community participation in the implementation of School Improvement Program in the study areas?

3. To suggest measure to be taken for the factors that hinder current community participation in the implementation of School Improvement Program in the study areas?

\section{Significance of this study:-}

The significance of this study was lie on what it describes to: - help for Zone Educational office, District /Woreda Education office, principal, PTA, KETB and SIC members to solve problems of current practice of community participation in School Improvement Program. The consumption of policy makers, at national or local levels and for practitioners to correct their weakness \& to suggest possible options for the improvement of current community participation in the implementation of School Improvement Program in the primary schools of Damot Woide Woreda/District, Wolaita Zone; And share experience about current practice of community participation in the implementation of school improvement program in the Primary schools; To provide valuable contribution to enhance community participation in School Improvement Program.

\section{Review Of Related Literature:- \\ The Concept of School Improvement:-}

In current climate, it is unreasonable for schools to decide to ignore approaches that bring change in schools. These days, school improvement is as an important process and becomes the dominant approach to educational change which helps to enhance quality of studentse learning and strengthen school's capacity for change (Hopkins, 2001). School improvement is about strategies for improving the school's capacity for providing quality education by focusing on pupil's learning.

There are reasons in which school improvements generally used. The first relates to general effort to make schools better places for students to learn. The second is a more technical in which school improvement is the strategies for educational change that enhance student outcomes as well as strengthening the schools ${ }^{\text {ee }}$ capacity for managing change (Hopkins and Stern, 1996). School improvement as a process involves the interaction of many people and changing school culture by reviewing teachers, school leaders, students and parents, as a central part of a change and demands improving and changing different situations in schools.

There are literatures that describe school improvement in terms of raising students ${ }^{\text {e }}$ achievement by focusing on the quality of teaching and learning in classrooms and the management arrangements that support it. In relation to this, Hopkins(2001) states school improvement as an approach to educational change that focuses on enhancing students achievement by modifying classroom practice and adapting management arrangement within the school to support teaching and learning or strengthen school's capacity for improvement. This shows that school improvement is an approach to educational change concerned with school process as well as student outcomes, and it is about enhancing teaching and learning as well as the conditions that support it. In line with this (MOE, 2007) stated that school improvement as a concept that focuses on increasing the academic performance of students by conducing self-evaluation on various school domains regarding the current situation of schools and by improving inputs and teaching process.

\section{School Improvement Program in Ethiopia:-}

The Education and Training Policy and its implementation document revealed the shortage in access of education to citizens and the low quality of education. To solve these problems there was the initiatives to develop the new Education and Training Policy. Different documents identified that, even if the implementation of the policy has improved the access of education, but the quality of education at different level wasn't improved. 
It was necessary to shift attention to quality concerns in general and to those inputs and processes which translate more directly into improved student learning and which help change the school into a genuine learning environment in particular. In order to improve the shortcomings related to quality, MOE launched the General Education Quality Improvement Package in 2007 (MOE, 2007). As in the document, the package consists of four major programs. Teachers Development program: Curriculum Improvement Program; Education Leadership and Organization Improvement Program; School Improvement Program, and two complementary packages; Civics and Ethical Education, and Information Communications Technology. Hence, School Improvement Program is among the programs designed to improve quality of education in the country. The School Improvement Program being implemented in Ethiopia to improve quality of education was adopted from the Australian school excellence initiatives; consist of four domains and twelve elements (MOE, 2007). The program was designed by MOE with different guiding manuals and then disseminated to regions, zones and schools for implementation. To ensure implementation of the program, trainings were given for different level educational leaders and expertise, and teachers. But most researchers stated that the stakeholders are not in position to help given adequate awareness to SIP.

\section{Rationales and Objectives of School Improvement Program:-}

School improvement is necessary for school to provide quality education by improving conditions under which teaching- learning takes place. The only way that school can survive and enhance quality in an era of change is through the school improvement (Hopkins et al., 1994). The principal focus of SIP in Ethiopia is to enhance the student achievement by improving the student learning and other conditions associated with it (MOE, 2007). The document also pointed out that the need of the school improvement program is to make schools accountable for parents, community and government to develop the responsibility and accountability of educational personnel's working at different level of the education system. The objectives of the school improvement program are to improve the capacity of schools, to prioritize needs and develop a school improvement plan, enhance school and community participation in resource utilization. The main aim of school improvement program is to provide suitable condition and environment for learning by increasing the participation of parents and the community and their feeling of responsibility in increasing their awareness regarding education and increase the quality of education by providing necessary resources through the coordination of the community, and non-governmental organizations.

\section{The Research Design And Methodology:-}

This chapter deals with the research method, source of data, sample and sampling techniques, instrument for data collection, pilot testing, procedures of data collection and methods of data analysis.

\section{The Research Design:-}

A mixed-methods approach was used in this study, combining both qualitative and quantitative components. A qualitative research is best used to discover themes and relationships at the case level while quantitative research is best used to validate those themes and relationships in samples and populations. According to Frankel and Wallen (2003) described a mixed - methods study as one containing both a quantitative and a qualitative portion. A mixedapproach design was employed in this study. The reason was that the researcher has used a mixed method approach to broaden understanding by incorporating both qualitative \& quantitative approaches to use one approach to better explain or build on the results from the other approach. Since the educational activities have been run by different stakeholders, were invited to have participation in the study. To utilize these stakeholders and for triangulation, the researcher was interested to use mixed method design for this study.

\section{Methods of the Study:-}

Data for the quantitative portion of the study were gathered. Explanatory and descriptive methodologies were comprised in the quantitative portion of the study. An explanatory design involves the researcher collecting and analyzing quantitative data, and then obtaining qualitative data to follow up and refine the quantitative finding (Frankel and Wallen, 2003). Descriptive research is a type of quantitative research that involves making careful descriptions of educational phenomena, concerned primarily with determining " what is."

Generally, to assess the factors that affect community participation in the implementation of School improvement program in primary schools of Damot Woide District, a descriptive survey design was employed. According to Gay, et al.(2000), descriptive survey design can be used to gather information about a group or individuals beliefs, attitudes, and to describe the current practice of the phenomenon and to interpret conditions or the current practice that are undergoing. The method is particularly important for the study to draw conclusions from the facts observed. 
Descriptive research is the "conditions or relationship that exist; practices that prevail; beliefs, point of views, or attitudes that are held; processes that are going on; efforts that are felt; or trends that are developing." Sometimes, descriptive research is concerned with how what exists is related to some preceding event that has influenced or affected a present condition or event. The descriptive research method is primarily concerned with portraying the present. In fact, the descriptive research method in educational research is not exactly a method because many approaches of data collection are grouped together. However, they have one element in common-each endeavors to depict the present position of a given situation. The main difference between various types of descriptive research is in the process of description (Verma \& Beard, 1981).

The research design chosen for this study is relevant because they are plan, structure and strategy conceived to obtain answers to the research questions. It is also presumed that the outcome of this study will not be the generalization of the result obtained, but give a profound understanding of the experiences from the perspectives of the selected participants for this study (Hopkins, \& Harris , 2000).

Survey research is considered a method of systematic data collection (Borg \& Gall, 1989). The purpose of survey research is to describe specific characteristics of a large group of persons, objects, or institutions (Jaeger, 1988). Surveys are one of the most commonly used methods of descriptive research in education and the other behavioral sciences. A survey involves the gathering of limited data from a relatively large number of cases at a particular time. This method is frequently employed to indicate prevailing conditions or particular trends. It is not concerned with characteristics of individuals as individuals, but it is concerned with providing information about population variables (Verma\& Beard, 1981). Nworgu (1991) observed that in survey research a group of people or items are studied by collecting and analyzing data from only a few people or items considered being representative of the entire group. Therefore, this study is essentially a descriptive survey research. It involves a study which is aimed at collecting data and describing it in a systematic manner, including the characteristics, features or facts about the given population in this study.

\section{Source of Data:-}

The data were gathered from primary and secondary sources to accomplish the study, to get reliable and valid information. The sources of primary data were school principal, teachers, parents and community representatives of PTA, KETB, SIC members, educational office quality Expert and school supervisor of Damot Woide District / Woreda. The secondary sources of data were School Improvement Program related documents such as, school improvement program guidelines, School Improvement Program Frame Work, Manuals, School Community participation plans, the three years plan of school improvement program of Primary School and different records of SIC in community participations with their achievements and challenges, Journals, other Legal Documents and Books.

\section{Samples and Sampling Techniques:-}

Eight sample primary schools were selected among 28 primary schools in the District. The target populations of this study were teachers, School principals; Primary school supervisors. community representatives (PTA, KETB and SIC members) as well as educational office heads and Quality Education experts..

\section{Teachers:-}

In the sample schools of this study, there are 286 teachers. From this 286 total teachers 129 teachers were selected first by stratified sampling then simple random sampling which is $45 \%$. From each department, teachers were selected using simple random sampling techniques from the total population, because in descriptive research, it is common to sample $45 \%$ to $50 \%$ of population numbers less than 500 (Gray, 1996).

\section{Parents or community representatives (PTA, KETB and SIC members) :-}

The total numbers of community representatives of the sample school were 24 PTA, 8 KETB and 40 SIC members and all are selected by using purposive sampling techniques. Because of their position and it was expected that they are partners either actual implementer or facilitators or evaluators of School Improvement Program in primary schools.

\section{Principals and educational officials :-}

Regarding principal, Vice-principals and Education officials, 16 principals, one quality education expert, One District/woreda Education Office Head and, 2 school supervisor were selected by purposive sampling technique. 
In general, 16 (100\%) principal, 24(100\%) PTA, 8(100\%) KETB, 40(100\%) SIC members, 129 (45\%) of teachers, $1(100 \%)$ Quality education experts, 2(100\%) of Primary school supervisor, \& 1(100\%) District /woreda Education office head with a total of 221 participants involved in the study.

Instruments of data collection:-

This study employed both quantitative and qualitative data. Both types of data were gathered by using appropriate data collecting tools in order to obtain sample information from respondents and school environment. The questionnaire was prepared for the major data collecting tool used in this study. Interview, document analysis and FGD was also another data gathering tools employed which help the researcher for enrichment and triangulation of the data obtained from questionnaires and provide in-depth information on the issue under investigation.

\section{Questionnaire:-}

Questionnaires was designed as both close ended and open ended items, distributed to teachers, community representatives PTA, KETB and SIC members. The Questionnaires were developed based on objective and purpose of the study using review of related literatures. It was distributed for all respondents by English language by the researcher. The amendment was made similar to plausibility wording style of the instrument. The five points of rating scale was employed to obtain close ended data from respondents and Open ended questionnaire were used to gather data from Teachers, KETB, PTA and SIC members of sample schools.

\section{Interview:-}

Interview conducted to gather data from educational officials and school principals concerning the participation of the community in the School Improvement Program. Leedy and Ormrod (2005) described that interview is a major tool in which a qualitative evaluator seek to understand the perceptions, feeling and knowledge of people in program through in-depth, intensive interviewing. Semi structured questions were used to guide the interview in the study.

\section{Focus Group Discussion:-}

The other data gathering instrument employed in this study was FGD. It was used to collect information from school SIC members in order to reveal the beliefs, attitudes, experiences and feelings of participants through interaction. Five FGDs members in each school, consists of totally 40 participants participated in the discussion. The time allotted for discussion was totally 4 hrs; that means an half hour was used for each FGD. Finally, the data obtained were triangulated with data obtained through other tools.

\section{Document Analysis:-}

Program related documents such as, school improvement program guidelines, School Improvement Program Frame Work, Manuals, School Community participation plans, the three years plan of school improvement program of Primary School and different records of SIC in community participations with their achievements and challenges, Journals, other Legal Documents and Books were analyzed.

\section{Procedures of Data Collection:-}

The researcher distributed the questionnaires to 129 teachers, 24 PTA, 8 KETB and 24 SIC members. The questionnaires were distributed after brief orientation about the purpose of the study and follow up was made collaboratively to each respondent. The questionnaires distributed to the respondents were collected after two days by the principals. All the distributed questionnaires were returned.

\section{Method of data analysis and Interpretation:-}

The purpose of this study was to assess the factors affecting current practice and challenges of community participation in the implementation of School Improvement Program in Damot Woide District/Woreda Primary schools. In order to achieve the objectives, the data obtained from different sources through different data gathering instruments was analyzed based on the nature of the data. Therefore, both quantitative and qualitative data used and analyzed accordingly. The data which obtained through questionnaires (teachers, PTA, KETB and SIC) was tallied, tabulated and the frequency, percentage, mean standard deviation and weighted mean were computed. The rated results of the items are taken as the average of their summation for purpose of presentation. Qualitative data analysis method was employed as a supplementary data analysis technique for triangulation and justification purpose. As a result, the data collected through interview (principals and educational official) open ended questions, FGD, and document review was narrated under quantitative data items related to it.

Validity and Reliability of the Instruments:- 


\section{Pilot Test:-}

To check the appropriateness of the items , pilot test was conducted in Bedessa Primary School which was not included in the sample study. A pilot study was conducted as a preliminary step to avoid errors. Its main objective is to detect possible weakness related to ambiguity due to poor morphological formulation and enable the researcher to make the necessary corrections and adjustments. To this end, the draft questionnaire were administered to 20 randomly selected teachers and 2 department heads of Bedessa Primary school. After the questionnaires filled and returned, the reliability \& validity of items were measured by using Cronbanch's alpha method with the help of SPSS version 20. Accordingly using Chronbach alpha, reliability of the questionnaire designed to be filled by teachers and department heads has got a reliability coefficient of 0.82 . This shows that the questionnaire designed for teachers has got a reliability. According to Cohen, et.al (2005) it is possible to use instruments with reliability coefficient of 0.7 and above. On the basis of obtained reliability coefficient, i.e. the feedbacks from a pilot study, the reliability coefficient obtained was 0.82 . This result show that the instrument (closed ended questions) prepared for the research were reliable, and comments from my senior staffs, some improvements were made on instructions and sequences of few items. Hence, the questionnaire was corrected, refined and made ready for final study by improving four items.

To be sure of the validity, senior colleagues would be invited to provide their comment. The participants of the pilot test should also first informed about the objectives and how to fill, evaluate and give feedback on the relevance of the contents, item length, clarity of items, and layout of the questionnaires. Moreover, to verify the content validity of the instrument, the questionnaire with sufficient number of items addressing all objectives of the study were administered to Primary school teachers and other participants in Damot Woide /District woreda.

\section{Result and Discussion, Conclusions and Recommendations:-}

This part deals with the result and discussion of the study, the conclusions drawn based on the findings and the recommendations that are assumed to improve the community participation in School Improvement Program in Damot Woide District /primary schools, Wolaita zone.

\section{Result and Discussion:-}

The purpose of this study was to assess factors affecting community participation in the school improvement program in Damot Woide District/primary schools ,Wolaita zone.

In order to achieve the desired objectives, the following basic questions were formulated:-

1. What are the school-community related factors/challenges that affect the community participation in the implementation of School Improvement Program in Damot Woide District /primary schools, Wolaita zone ?

2. What measure should be taken for the factors/challenges that are hindering community participation in the implementation of School Improvement Program in the study areas?

In dealing with the problems, both quantitative and qualitative approaches were used to assess the factors affecting community participation in the implementation of School Improvement Program. Descriptive survey was employed in this study because this design enables the researcher to gather relevant and adequate information on the issues considered. The study was conducted in Damot Woide District/primary schools , Wolaita zone. On the basis of the research questions, the researcher used different data collecting instruments such as questionnaires, interview, Document analysis and FGD.

Based on analysis and interpretation of the data, the following major findings were found out. The community of the school (principals, teachers, PTA, KETB and SIC) to empower community by giving training and orientation was rated a weighted mean values of 3.93. This shows that there is high challenge for community participation in School Improvement Program.

The study revealed that a weighted mean value rated 3.36. 3.84 and 3.8 was hindrance of community participation due to reluctance of the community to participate in the identification of the need assessment, planning, implementation and evaluation process; lack of community participation in decision making process of the school management and lack of good governance and leadership skills of the principal.

The sample school has lack of well-developed school policies, rules, regulation, norms and no appropriate strategy for the school to encourage and provide community services, information about school improvement program. The 
weighted mean value of 3.67 indicated that it was great challenge for current community participation in SIP/School Improvement Program.

Awareness of a community about roles and responsibilities in School Improvement Program and an inappropriate ownership and responsiveness of the community towards the school to participate in School Improvement Program was rated a weighted mean value of 3.36.and3.67 respectively. From this one can conclude that there was lack of awareness of a community about roles and responsibilities in School Improvement Program and an inappropriate ownership and responsiveness of the community towards the school were challenges for community participation in SIP/School Improvement Program in the sample schools.

The sample school has lack of finance (economic problems on the parts of the society) to support School Improvement Program and lack of Participation of community in different school meetings to discuss effectiveness and efficiency of the school, lack of awareness or information about roles and responsibilities of the community in School Improvement Program and poor follow up of the community to their children in close relation to the school was rated with a weighted mean value of $3.44,3.67$ and 3.51 respectively. From this one can conclude that these factors were one of the main challenges for community participation in SIP/School Improvement Program in the sample schools

\section{Conclusions:-}

Based on the result of the study, the following major conclusions were drawn:-

Community participation is not adequate to the implementation of School Improvement Program in Damot Woide District/primary schools, Wolaita zone. This inadequate participation is because of some of the factors related to the community and the school. The challenges which related to the school were reluctance of the community to participate in identification of the need assessment, planning, implementation and evaluation process, lack of fixed time schedule to deal with the community about School Improvement Program. Due to this factors, the schools faced a great problem of getting the community to work and discuss with them.

The schools lack well-developed school polices rules, regulation and norms to participate the community as a member of the school. In most cases, the reluctance of the community to participate actively in School Improvement Program due to lack of good governance and poor quality of principal in leadership skill, poor commitment of the school community (teachers, PTA, KETB and SIC) to involve the community in School Improvement Program and weak strategy for the school to provide community services and recent information about School Improvement Program were among the factors that contribute to the low level of community participation in School Improvement Program.

The Domain of community participation can be stated in various ways, depending on the context of school improvement program. It also consists of three elements and each element has its own standards. Element one of community participation domain stated that "working with parents"e. The standards of this element describe teachers meet with parents when necessary and at a minimum twice per-semester to provide quality reports and to discuss their child's learning achievements. But the sample school teachers of the study zone were lack of any fixed schedule to deal with the community/parents. As a result the parents would have limited information, communication and support about their children education in the school.

Element two of community participation domain describe about "society participation" the standards of this element stated that "school successfully mobilized the community to provide resources to support the implementation of the school improvement program. When we came to the study district /zone, the communities provide not to the expected level of resources to support implementation of school improvement program. This condition caused scarcity of the resource. Finally it was caused to low students' achievements.

Element three of community participation domain emphasized on "promoting education". The standard of this element stated that schools are active in communicating and promoting the importance of education in the community. But the sample school of the study district /zone had no appropriate network/channels to communicate with the community to promote the importance of school improvement program /education. Even if they had meeting at the end of first semester and end of the year, the number of parents come to the schools were very few. 
Active community participation in School Improvement Program contributes to higher achievement of students and improves school environment. It is also crucial for implementation of effective teaching learning processes to assure quality of education. The school and parent relationship must be maintained through the continuous clear exchanging of information between both sides (the parents and the school). Parents have to involve in their children's education activity, if they know how to help their children. They must be initiated by schools to be aware of their roles and responsibilities they can discharge in the schools.

\section{Recommendation:-}

Depending on the findings and the conclusion of the study, the following recommendations were forwarded:

The schools Administrators, PTA, KETB and SIC members and educational officials should have the responsibilities to provide the community with complete and accurate information regarding school improvement goals and program, and community duties and responsibilities on School Improvement Program.

Schools, WEO, Zone Education Department, and REB should create a program for sharing of experience to KETB and PTAs to give them the chance to learn from other schools, Districts, and Zones who have a better performance in the participation of the community in the school activities.

Every stakeholder has the responsibilities to know what the school does in relation to School Improvement Program, its problems and opportunities to solve the problems. The school principals and teachers should have the responsibilities to give parent community and the whole community with clear and accurate information regarding the objective of education, school goals and program, prepare training programs for parents to work together with the school.

School should have to promote collaborative structures of organizational conditions. This condition should promote effective professional learning that depends largely on its organizational culture such as belief, attitudes, value, knowledge, norms, rules, regulation and skills which enhance partnership with community.

The school system should have a shared responsibility to improve students' learning out comes. The partners' and communities should have to know the specific areas of education like need assessment, setting priorities, contributing resources, policy making and governance (the setting goals, planning of programs and managing of budget) and the instructional process.

The District school-board and KETB should help to set direction and provide support for active participation of community in the School Improvement Program. The District school Board and KETB improve community participation by providing training programs and forums for the community about School Improvement Program.

\section{Acknowledgements:-}

First of all, I would like to thank my staff members of the institute of education and professional development studies of Mettu University who gave me their valuable experience in conducting and finalizing this research.

I would also express my deep gratitude to all the principals, teachers, KETB, PTA, SIC, and educational experts of Damot Woide District of Wolaita Zone for their cooperation and commitment in giving valuable information during my research study. Moreover, I would like to take this opportunity to express my appreciation to my colleagues , families, and relatives who contributed in different ways for the success of this study 


\section{References:-}

1. Anderson, B.M. (1992).Education for all. What are we waiting for? New York: United Nation children's fund program publications, U.S.A.

2. Ayalew Shibeshi (1991).Approach to Educational organization and management. A.A.U unpublished.

3. Borg, W.R. and Gall, M.D (1989). Educational Research: An Introduction. (5 ${ }^{\text {th }}$ Ed). New York: Longman.

4. Cohen, L., Manion, L. and Mornison, k.(2005).Research Methods in Education ( $5^{\text {th }}$ ed). New York: Rout ledge.

5. Frankel, J.R. and Wallen, N.E.(2003). How to Design and Evaluate Research in Education (5 ${ }^{\text {th }}$ ed). New York: MacGraw -Hill.

6. Gay,L.R. and Airaisian, P.(2000). Educational research: Competencies for analysis Application.(6 ${ }^{\text {th }}$ ed).New Jersey: Prentice Hall.

7. Gray,(1996). Research Methodology. USA. Philadelphia, Management Group,Inc..

8. Hopkins ,D. A and Ilu, M. (1994). School Improvement an Era of change. .New York: Cassel.

9. Hopkins ,D. and Stern (1996). Teachers Quality, Quality Schools : International Perspectives and Policy Implication. Teaching and Teacher Education, vol. 12, 501-517.

10. Hopkins ,D. and Harris, A.(2000). Creating the Condition for Teaching and Learning. London, David Fulton.

11. Hopkins ,D. (2001). School Improvement for Real. London, Rout ledge.

12. Jaeger, R. M., (1988). Complementary Methods for Research in Education. American Educational Research Association. Washington, DC.

13. Leedy, P.D and Ormond, J.E(2005). Practical Research Planning and Design ( $8^{\text {th }}$ ed $)$. New Jersey: Pearson Prentice Hall.

14. MOE (1994).Education and Training Policy: Addis Ababa: Ministry of Education.

15. ._ (2002). Guideline for organization of educational management, community participation and educational finance. Addis Ababa Unpublished.

16. 2004). School Improvement Program Implementation Guideline. Addis Ababa.

17. _ (2005). Education Sector Development Program III: Program Action Plan. Addis Ababa.

18. (2007).School Improvement Program Frame Work. Addis Ababa: EMPDA.

19. Nworgu, B. G. (1991). Educational Research: Basic issues and methodology. Ibadan: Wisdom Publishers.

20. Stoll . L and Dean. F ( 1996) . Changing out Schools. London Open University Press.

21. World Bank (1988). Ethiopian Social Sector Report: A world Bank Country Study, USA: The World Bank.

22. Verma, G. \& Beard, R. (1981). What Is Educational Research. London: Gower. 